\title{
Factors affecting the purchasing of rabbit meat: A study of ethnic groups in the Western Cape
}

\author{
LC Hoffman, Pulane Nkhabutlane, De W Schutte \& Charlyn Vosloo
}

\section{OPSOMMING}

Die bemarking van konynvleis in ander lande het ' $n$ verskuiwing ondergaan, van die verkoop van heel konynkarkasse tot die later ontwikkeling van die verkoop van konynvleis in porsies as 'n geriefsverpakking. Ander bemarkingsvraagstukke met betrekking tot konynvleis, byvoorbeeld of daar 'n mark daarvoor is, is nie ondersoek nie. In hierdie studie is die bemarkingspotensiaal van konynvleis ondersoek. Die beskrywende opnamemetode, wat gebruik maak van 'n gestruktureerde vraelys, is gebruik en toegepas op 304 respondente. Die gemiddelde waardes van faktore wat die bemarking en aankoop van konynvleis beïnvloed, is bereken. Dit was bepaal dat die mark vir konynvleis nog baie beperk is. Slegs $43 \%$ van die respondente wat wel konynvleis verbruikers is, het aangedui dat hulle een of twee keer per maand konynvleis sal wil eet, waarvan 29 swart, agt wit en 23 bruin respondente was. Die voorgenome frekwensie van inname van die res van die verbruikers van konynvleis was een of twee keer per jaar. Die resultate dui daarop dat respondente, wat verbruikers van konynvleis is, dit sou verkies om konynvleis in porsies (53\%), eerder as die hele karkas te koop. Indien vars verkoop, sal dié porsies die bemarkbaarste wees. Varsheid is deur al die respondente, ongeag etniese groep, as die belangrikste kwalitatiewe eienskap van konynvleis beskou. Die meeste respondente het aangedui dat hulle die agter- en voorbeen, en borsgedeeltes as porsies sal verkies, met die agterbeen as die mees gewilde gedeelte en die borsgedeelte as die minste gewild. Die verskille wat waargeneem is in die opinies met betrekking tot die bemarking van heel karkasse, het aangedui dat die swart respondente die kop saam met die karkas sou wou koop. Die hoofrede vir dié voorkeur, is dat hulle wil seker maak dat die karkas wat aan hulle verkoop word, inderdaad dié van 'n konyn is, en nie van 'n kat nie.

Die respondente wat verbruikers van konynvleis is, het aangedui dat hulle sou verkies om die aankoop van konynvleis te beperk tot supermarkte $(41 \%)$, slagters (44\%), jagters (30\%) en restaurante (23\%), eerder as om konynvleis van telers te verkry. Maksimum verkope van konynvleis kan bereik word deur 'n manipulasie van die verkoopprys. Resultate het aangedui dat die meeste respondente (61\%) sou verkies om konynvleis teen 'n prys laer as dié van hoender aan te koop, terwyl $37 \%$ gewillig sou wees om meer vir konynvleis as vir hoender te betaal. Die verwagtinge en voorkeure van die verskillende respondente met betrekking tot konynvleis is ' $n$ belangrike faktor wat in gedagte gehou moet word by die bemarking daarvan. Blanke responden- te het aangedui dat hulle die vleis van maer, jong (sagte) konyne sal verkies, terwyl swart respondente aangedui het dat hulle ' $n$ voorkeur sou hê vir vetterige, taaier konynvleis.

\section{- Prof LC Hoffman \\ Department Animal Sciences \\ University of Stllenbosch}

\section{- MS P Nkhabutlane}

Department of Consumer Science

University of Stellenbosch

- Dr De W. Schutte

Unisearch Research Consultants

Strand

\section{- Dr MC Vosloo}

Department of Consumer Sciences

University of Stellenbosch

\section{INTRODUCTION}

Recent studies indicate that consumer food choices are influenced by health, taste, convenience, visual appeal and reasonable prices (Mermelstein, 2002; Stillings, 1994). The main interest of consumers is to eat foods that provide more than the known traditional nutritional benefits in the sense that they tend to view food as medicine, because they are aware that prevention is better than treatment or cure (Mermelstein, 2002; Sloan, 1999). They are therefore obsessed with so-called healthy foods, which are perceived to make them feel and look better. These products are characterised by fewer kilojoules, less fat and lower cholesterol (Stillings, 1994).

Sonandi et al (1996) outlined some of the main factors which inhibit the popularity of rabbit meat, including lack of consumer appeal. They found that a large percentage of consumers of rabbit meat do not like the rabbit carcass to be presented whole, as it resembles a cat or a human infant. More recent research by Piles et al (1999) also recommended a shift from commercialising rabbit as a whole carcass, to selling rabbit meat as retail cuts. Presentation of the carcass, either whole or in portions, influences the slaughter weight. Eady and Prayaga (2000) stated that, according to the Australian market demand, rabbits sold as a whole carcass in butcher shops are slaughtered at 1,0 to $1,3 \mathrm{~kg}$, while those portioned for the restaurant trade 


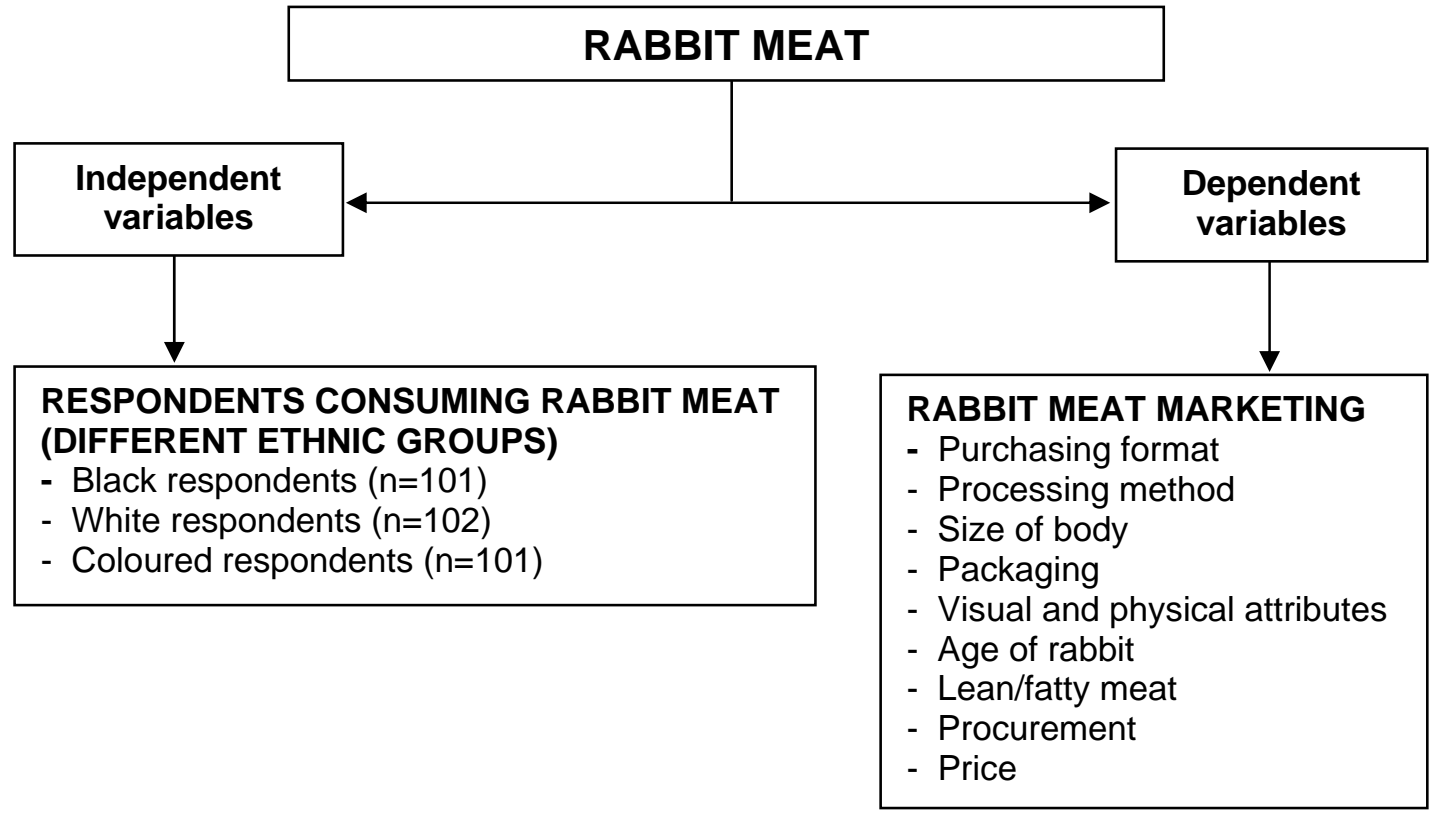

FIGURE 1:

CONCEPTUAL FRAMEWORK OF THE STUDY, DEPICTING THE INDEPENDENT AND DEPENDENT VARIABLES

are slaughtered at 1,4 to $1,7 \mathrm{~kg}$. The differences in slaughter weight are associated with differences in growth period on the farm. These new trends towards portioning for the sake of convenience are accompanied by a change in rabbit meat programmes, and involve increased meat yields and appreciated production traits (Piles et al, 1999). Rabbits to be processed for portions stay on farms longer and will thus obtain a higher sales price, but this would involve other economic disadvantages.

The relevance of rabbit meat in the diet and a better understanding of consumer decisions to purchase rabbit meat are of paramount importance, due to distinct changes at the consumer level. Comprehensive planning and research must take place before a farmer decides to start breeding rabbits for commercial rabbit breeding to be profitable (Green, 1999). In this regard it is important to remember that marketing of the meat is the most important part when farming with rabbits, and it is also the most difficult and time consuming. The issues underlying the marketing strategies include the increasing importance of quality, organoleptic and sensory properties of food in general as well as issues relating to food safety and human health.

Gittens (2000) reported that there was a potential for the marketing of rabbit meat in South Africa, especially in the rural areas, as previous studies had already determined that the demand exceeded the supply. This was confirmed by Billet (1992), who indicated that the rabbit meat industry was showing promise in Gauteng. In addition, Billy David and Mary Carr, cited by Billet (1992), have a strong feeling that the meat market in Johannesburg is undersupplied. They predict that the demand is likely to grow as the country becomes more cosmopolitan, because there is a niche market for rabbit meat in South Africa among the Caucasian population, particularly people of French, Portuguese and Italian origin and other residents of European descent.

There is scant knowledge regarding the marketing factors that affect the purchasing of rabbit meat. Therefore this study was undertaken to establish marketing factors that may affect the consumption of rabbit meat amongst respondents who consume rabbit meat. Refer to the conceptual framework of the study indicated in Figure 1.

\section{METHODOLOGY}

\section{Research design}

A quantitative research technique was used because it was considered to be most suited to the aim of the research. The purpose of this survey was to investigate marketing factors affecting the purchasing of rabbit meat in a town in the Western Cape. To meet this objective the descriptive survey method was employed, using a structured questionnaire to provide data on consumers' opinions towards rabbit meat.

\section{Study population}

The study population consisted of respondents from three South African racial groups (black, coloured and 
white), of different ages and various educational levels. A sample of 304 consumers was randomly drawn from the population residing in the Stellenbosch area and a representation from each ethnic group, namely black $(n=101)$, coloured $(n=101)$ and white respondents $(n=102)$ was used. To achieve a random selection, the proportional systematic sampling technique was used (Frankfort-Nachmias \& Nachmias, 1996:187). This involved deciding on the number of respondents per ethnic group, and counting residential houses from property layout maps of the Stellenbosch area, deciding on the number of respondents required from each area and dividing the number of houses by the sample size decided upon for each ethnic group. A random figure determined the starting point for the systematic sequence to select ethnic respondents. The identified houses were then marked on the area maps and an address list was compiled from the chosen respondents to substantiate the map. Interviews were conducted in Stellenbosch from May 2003 to June 2003. The residential areas included were Idas Valley and Cloetesville for the coloured, Kayamandi for black and Uniepark, Mostertsdrift, Dalsig, Universiteitsoord, La Colline, Kromriver, Die Boord, Paradyskloof and Onder-Papegaaiberg for white respondents.

\section{Survey instrument}

The survey instrument was designed to examine the effect of ethnicity on marketing factors of rabbit meat. The dendrogram technique (Schutte, 1992), analogous to the conceptual framework explained by Frankfort-Nachmias and Nachmias (1996:33), served as the foundation for the design of the survey questionnaire. This technique was applied after the boundaries for the theory were defined during a comprehensive literature review and acted as a guide for asking relevant questions within the scope of study. This technique involves the construct 'rabbit meat marketing' and identifying relevant sub-concepts at the second level, which define the questions of the questionnaire at the third level. In this way, the research moves from theoretical constructs to the operational level.

The survey instrument was divided into three parts. The first part was to be filled in by all respondents, the second part was meant for those who eat meat, even if they do not eat rabbit meat, while the last part was only for those who had eaten rabbit meat before or who were willing to eat rabbit meat if it was available. This division of the questionnaire in sections resulted in a variation in the total number of respondents per question. Some of the questions were open-ended and others closed.

The preliminary questionnaire was evaluated by a panel of people from the disciplines of Animal and Consumer Sciences. The questionnaire was pretested by the researchers in the particular ethnic groups ( 5 from each group) amongst students on the campus of Stellenbosch University before collection of data commenced. Relevant changes were made to the questionnaire pertaining to these findings.

\section{Data collection and organisation}

Three well-experienced fieldworkers were used for the collection of data, after having been screened for suitability as interviewers in the particular areas. They were given thorough training to minimise problems that might affect the reliability of the results.

The data obtained from the questionnaire were organised by coding the open-ended questions, in order to prepare them for data capturing.

\section{Data analysis}

The data were entered into a Microsoft Excel spreadsheet. The quantitative data was then subjected to the 8,2 version of the SAS package (1999) for quantifying means, standard deviations, frequencies and percentages. The statistical significance level of differences between the dependent and independent variables was determined by Chi-square tests at $p<0,05$.

\section{RESULTS AND DISCUSSION}

\section{Consumption of rabbit meat}

According to the results, $47 \%(n=142)$ of the respondents in the Western Cape had eaten rabbit meat before at different places, such as at home, at restaurants and from hunting. It was clear that more of the black ethnic group $(n=62)$ had consumed rabbit meat before than of the other groups (white, $n=44$; coloured, $\mathrm{n}=36$ ). This experience in rabbit meat consumption seemed to contribute positively to the desire to eat it again (Table 1). It was further found that more than half $(52 \%, n=158)$ of the respondents had never eaten rabbit meat before. However, $46 \%(n=73)$ of these respondents showed the desire to consume rabbit meat if available.

\section{The potential for marketing rabbit meat}

To establish whether there is a potential market for rabbit meat in the Western Cape, all the rabbit meat consumers $(n=142)$ were asked to indicate the number of times that they would like to be able to eat rabbit meat. Thirty per cent $(n=42)$ of the respondents indicated that they would like to have rabbit meat twice a month. The ethnic groups differed significantly $(p<0,01)$ in this regard (see Table 1$)$. The black respondents constituted the highest percentage $(67 \%$, $n=28)$, followed by coloured $(31 \%, n=13)$ and white respondents with $2 \%(n=1)$ (Table 1). Asp (1999) explains the fact that people who have never been exposed to certain foods, will register a dislike for that particular food, which explains the low percentage of white respondents willing to consume rabbit meat regularly (Table 1$)$.

\section{Purchasing format of rabbit meat}

Differences regarding the preferences for the purchasing format of respondents from different ethnic groups who consume rabbit meat are shown in Table 2. 
TABLE 1:

THE FREQUENCY AT WHICH CONSUMERS OF RABBIT MEAT WOULD CHOOSE TO EAT RABBIT MEAT ( $n=142) *$

\begin{tabular}{|l|c|c|c|c|}
\hline $\begin{array}{c}\text { Number of times } \\
\text { willing to eat } \\
\text { rabbit meat }\end{array}$ & $\begin{array}{c}\text { Black respon- } \\
\text { dents (n=62) }\end{array}$ & $\begin{array}{c}\text { White respondents } \\
(\mathbf{n = 4 4 )}\end{array}$ & $\begin{array}{c}\text { Coloured respon- } \\
\text { dents }(\mathbf{n = 3 6 )}\end{array}$ & $\begin{array}{c}\text { Total \% respon- } \\
\text { dents }(\mathbf{n}=\mathbf{1 4 2})\end{array}$ \\
\hline No response & 22 & 12 & 7 & 29 \\
\hline 2/month & 28 & 1 & 13 & 30 \\
\hline 1/month & 1 & 7 & 10 & 13 \\
\hline 2/year & 3 & 9 & 1 & 9 \\
\hline 1/year & 8 & 15 & 4 & 19 \\
\hline When available & 0 & 0 & 1 & $<1$ \\
\hline
\end{tabular}

* The numbers in the first three columns are the actual number of responses out of the total indicated at the top of the column, while the last column represents the $\%$ of the total number of respondents

TABLE 2: $\quad$ THE PREFERENCE FOR THE PURCHASING FORMAT OF RABBIT MEAT PER ETHNIC GROUP $(n=142)^{*}$

\begin{tabular}{|l|c|c|c|c|}
\hline $\begin{array}{c}\text { Purchasing } \\
\text { format }\end{array}$ & $\begin{array}{c}\text { Black respon- } \\
\text { dents (n=62) }\end{array}$ & $\begin{array}{c}\text { White respon- } \\
\text { dents }(\mathbf{n}=\mathbf{4 4})\end{array}$ & $\begin{array}{c}\text { Coloured respon- } \\
\text { dents }(\mathbf{n = 3 6})\end{array}$ & $\begin{array}{c}\text { Total \% respon- } \\
\text { dents (n=142) }\end{array}$ \\
\hline No response & 13 & 8 & 7 & 19 \\
\hline Live & 8 & 2 & 1 & 8 \\
\hline Whole & 14 & 5 & 8 & 19 \\
\hline Portions & 27 & 26 & 20 & 51 \\
\hline Live \& portions & 0 & 3 & 0 & 2 \\
\hline
\end{tabular}

The numbers in the first three columns are the actual number of responses out of the total indicated at the top of the column, while the last column represents the $\%$ of the total number of respondents

TABLE 3: $\quad$ PREFERENCE FOR RABBIT CARCASS CUTS $(n=142)$

\begin{tabular}{|l|c|c|c|c|}
\hline Carcass cuts & No response (n) & $\begin{array}{c}\mathbf{1 - 3} \text { (prefer less) } \\
(\mathbf{n})\end{array}$ & $\begin{array}{c}4-6 \text { (prefer } \\
\text { moderately) (n) }\end{array}$ & $\begin{array}{c}\mathbf{7 - 9} \text { (prefer to } \\
\text { large extent) (n) }\end{array}$ \\
\hline Back legs & 73 & 11 & 14 & 44 \\
\hline Chest & 77 & 8 & 23 & 34 \\
\hline Front legs & 77 & 5 & 24 & 36 \\
\hline Ribs & 86 & 14 & 27 & 15 \\
\hline Neck & 97 & 22 & 11 & 12 \\
\hline Head & 107 & 31 & 1 & 3 \\
\hline
\end{tabular}

TABLE 4: $\quad$ PREFERENCE FOR METHOD OF PROCESSING $(n=142)^{*}$

\begin{tabular}{|l|l|l|l|l|}
\hline $\begin{array}{c}\text { Form of rabbit } \\
\text { meat }\end{array}$ & $\begin{array}{c}\text { Black respondents } \\
(\mathbf{n = 6 2})\end{array}$ & $\begin{array}{c}\text { White respon- } \\
\text { dents }(\mathbf{n = 4 4 )}\end{array}$ & $\begin{array}{c}\text { Coloured respon- } \\
\text { dents }(\mathbf{n}=\mathbf{3 6})\end{array}$ & $\begin{array}{c}\text { Total \% respon- } \\
\text { dents }(\mathbf{n}=\mathbf{1 4 2})\end{array}$ \\
\hline No response & 13 & 7 & 9 & 20 \\
\hline Fresh & 30 & 28 & 22 & 56 \\
\hline Frozen & 16 & 7 & 4 & 19 \\
\hline Canned & 3 & 2 & 0 & 4 \\
\hline Canned \& Frozen & 0 & 0 & 1 & $<1$ \\
\hline
\end{tabular}

The numbers in the first three columns are the actual number of responses out of the total indicated at the top of the column, while the last column represents the $\%$ of the total number of respondents 
As indicated in Table 2, 51\% of the respondents who consume rabbit meat would prefer to buy the meat in portions, rather than as the whole carcass (19\%). The results are in agreement with Sonandi et al (1996) who found that, in South Africa, a large number of consumers of rabbit meat (79\%) do not like rabbit meat to be presented in a whole carcass, as it resembles a cat or a human infant. This may be attributed to the fact that, although rabbit used to be commercialised as a whole carcass, a trend of selling rabbit in retail cuts is developing (Piles et al, 1999). Today convenience is of paramount importance as time-pressed consumers do not easily accept products that are considered to take too long to prepare (Allen, 1995). Consumers continue to seek simplicity in their lives (Sloan, 2002), and pre-portioning rabbit meat is an important step towards convenience.

Purchasing rabbit meat in portions was preferred by all ethnic groups, but more so by white respondents (59\%) than coloured respondents (56\%) and black respondents $(44 \%)$. The preference for buying rabbit meat in portions by white respondents who had a higher household income (Nkhabutlane, 2004:95-96) was expected. Packaging in portions provides convenience for housewives and help consumers to cope with the busy life styles of today (Dalle Zotte, 2002). The other reason for the popularity of the rabbit portions, is the fact that it adds more profit per portion than the whole carcass. Dalle Zotte (2002) noted that the trend for selling rabbit meat in cuts or pre-cooked is increasing and this consequently increases the price, but consumers do not hesitate to pay higher prices due to convenience. It therefore becomes very important to identify the specific cuts of a rabbit carcass that are most preferred by consumers. In this regard respondents were asked to rate their preferences for the different cuts of rabbit meat on a nine point scale from prefer less (1) to prefer most (9). The results revealed that preference for rabbit back legs was rated the highest $(n=44)$, followed by the front legs $(n=36)$ and chest $(n=34)$ (Table 3$)$.

\section{Processing method of rabbit meat}

Results (Table 4) revealed that the respondents who consume rabbit meat prefer to purchase fresh meat $(56 \%)$, instead of frozen $(19 \%)$ or canned $(4 \%)$. A significant difference $(p<0,01)$ was observed between ethnic groups regarding this issue. Fresh rabbit meat was preferred more by white (64\%) and coloured respondents $(61 \%)$, fewer black respondents $(48 \%)$ preferred fresh meat. When asked for their reasons for their choice of processing methods, they argued that fresh meat is healthier. In addition to that, they said the taste, texture and flavour are at their best whilst fresh. This is the reason why most stores should give preference to fresh rabbit meat over frozen. This entails having to deliver the meat to stores as quickly as possible after slaughtering, processing and packaging, since stores rely heavily upon the ability to display the fresh product for a number of days.

Nineteen per cent of the respondents indicated that they prefer frozen rabbit meat. In this regard, more black respondents preferred frozen meat (26\%) than white $(16 \%)$ or coloured respondents (11\%). Meat retailers are likely to be aware of the fact that fresh rabbit meat under refrigeration has an approximate shelf life of six days, and that rabbit meat not on display will be frozen and thawed as needed (Sandford, 1986:200-201; Lamar, 1998). A variety of reasons for this preference was mentioned, which included the fact that respondents are used to buying frozen chicken, so they feel rabbit meat should also be presented frozen, just like chicken. They said it does not immediately give the impression that it was slaughtered when it is frozen. These consumers also indicated that they do not like the flavour of fresh meat, so they believe that flavour will improve with storage. Sandford (1986:200-201) documented that freezing dries out the meat and causes it to lose some of its flavour. To overcome this, rabbit portions should be arranged in special packaging material and sealed before being frozen. There was yet another group of respondents $(4 \%)$ who indicated that, due to the convenience and evident storage advantage of canned meat, they would prefer that option.

Results showed that if a rabbit is presented as a whole carcass, $42 \%$ of the respondents that consume rabbit meat would prefer the carcass without the head (Table 5). There was a significant difference between the three ethnic groups $(p<0,01)$ regarding this issue, in that there were more white $(61 \%)$ and coloured $(42 \%)$ than black $(29 \%)$ respondents who indicated that they do not eat the head. Some $(22 \%)$ of the respondents indicated that they would only buy a rabbit carcass with the head attached to ensure that it was indeed a rabbit. More black respondents (45\%) stipulated this criterion than coloured $(8 \%)$ and white respondents (0\%).

\section{Body size}

Another factor which may influence the respondents' choice of rabbit meat could be the size of the body of the rabbit. Considering the fact that the size is a factor of rabbit breed, it is therefore important to note the characteristics of different breeds. The body of the California rabbit is of medium length with welldeveloped shoulders and hindquarters (Arrington \& Kelly, 1976:176-201). Medium breeds are recommended for meat production because they are more economical than the large breeds, which need to be fed more, but do not produce much more meat. Hence a commercial producer should consider table rabbits that are likely to weigh $2 \mathrm{~kg}$ at an age of nine to ten weeks, and that will produce the greatest amount of profit.

There was a significant difference $(p<0,01)$ between the ethnic groups concerning the type of rabbit body that they prefer (Table 6). Slightly more respondents who consume rabbit meat would buy a rabbit with a short body (20\%). More black (34\%) than coloured $(11 \%)$ or white $(9 \%)$ respondents preferred short body rabbits. The reasons given for the choice were that rabbits with short bodies are more tender and they have an attractive appearance. These findings are 
TABLE 5: INFLUENCE OF ETHNIC GROUPING ON THE CHOICE OF RABBIT CARCASS $(n=142)$ *

\begin{tabular}{|l|c|c|c|c|}
\hline \multicolumn{1}{|c|}{ Carcass choice } & $\begin{array}{c}\text { Black respon- } \\
\text { dents }(\mathbf{n = 6 2})\end{array}$ & $\begin{array}{c}\text { White respon- } \\
\text { dents }(\mathbf{n = 4 4 )}\end{array}$ & $\begin{array}{c}\text { Coloured respon- } \\
\text { dents }(\mathbf{n = 3 6 )}\end{array}$ & $\begin{array}{c}\text { Total \% respon- } \\
\text { dents }(\mathbf{n}=\mathbf{1 4 2})\end{array}$ \\
\hline No response & 9 & 9 & 9 & 19 \\
\hline Don't know & 7 & 8 & 9 & 17 \\
\hline Carcass without head & 18 & 27 & 15 & 42 \\
\hline Carcass with head & 28 & 0 & 3 & 22 \\
\hline
\end{tabular}

TABLE 6: $\quad$ EFFECT OF SIZE OF BODY ON THE CHOICE OF RABBIT CARCASS $(n=142)$ *

\begin{tabular}{|l|c|c|c|c|}
\hline \multicolumn{1}{|c|}{ Body of rabbit } & $\begin{array}{c}\text { Black respon- } \\
\text { dents (n=62) }\end{array}$ & $\begin{array}{c}\text { White respon- } \\
\text { dents }(\mathbf{n}=\mathbf{4 4})\end{array}$ & $\begin{array}{c}\text { Coloured respon- } \\
\text { dents }(\mathbf{n = 3 6 )}\end{array}$ & $\begin{array}{c}\text { Total \% respon- } \\
\text { dents }(\mathbf{n}=\mathbf{1 4 2})\end{array}$ \\
\hline No response & 20 & 37 & 26 & 58 \\
\hline Short body & 21 & 4 & 4 & 20 \\
\hline Long body & 17 & 2 & 6 & 18 \\
\hline Don't know & 4 & 1 & 0 & 4 \\
\hline
\end{tabular}

* The numbers in the first three columns are the actual number of responses out of the total indicated at the top of the column, while the last column represents the $\%$ of the total number of respondents

TABLE 7: $\quad$ ATTENTION TO PACKAGING OF RABBIT MEAT FOR THE ETHNIC GROUPS $(n=142)$ *

\begin{tabular}{|l|l|l|l|l|}
\hline $\begin{array}{c}\text { Attention to rabbit } \\
\text { meat packaging }\end{array}$ & $\begin{array}{c}\text { Black respon- } \\
\text { dents }(\mathbf{n}=\mathbf{6 2})\end{array}$ & $\begin{array}{c}\text { White respon- } \\
\text { dents }(\mathbf{n = 4 4 )}\end{array}$ & $\begin{array}{c}\text { Coloured respon- } \\
\text { dents }(\mathbf{n = 3 6})\end{array}$ & $\begin{array}{c}\text { Total \% respon- } \\
\text { dents }(\mathbf{n = 1 4 2})\end{array}$ \\
\hline No response & 9 & 9 & 15 & 23 \\
\hline No & 34 & 13 & 11 & 41 \\
\hline Yes & 22 & 10 & 36 \\
\hline
\end{tabular}

* The numbers in the first three columns are the actual number of responses out of the total indicated at the top of the column, while the last column represents the $\%$ of the total number of respondents

TABLE 8: THE EXTENT TO WHICH MEAT QUALITIES ARE CONSIDERED BY RABBIT MEAT CONSUMERS $(n=142)$

\begin{tabular}{|l|l|l|l|l|}
\hline $\begin{array}{c}\text { Visual and physical } \\
\text { attributes }\end{array}$ & No response & $\begin{array}{c}\text { 1-3 (consider } \\
\text { less) (n) }\end{array}$ & \multicolumn{1}{c|}{$\begin{array}{c}\text { 4-6 (consider } \\
\text { moderately) (n) }\end{array}$} & $\begin{array}{c}\text { 7-9 (consider to a } \\
\text { large extent) (n) }\end{array}$ \\
\hline Colour & 85 & 9 & 18 & 30 \\
\hline Shape/arrangement & 84 & 5 & 12 & 41 \\
\hline Weight & 91 & 5 & 5 & 41 \\
\hline Odour & 87 & 11 & 13 & 31 \\
\hline
\end{tabular}

TABLE 9: DISTRIBUTION OF CONSUMER'S PREFERENCE FOR A YOUNG OR OLD RABBIT*

\begin{tabular}{|l|c|c|c|c|}
\hline $\begin{array}{c}\text { Age of rabbits for } \\
\text { meat }\end{array}$ & $\begin{array}{c}\text { Black respon- } \\
\text { dents }(\mathbf{n}=\mathbf{6 2})\end{array}$ & $\begin{array}{c}\text { White respon- } \\
\text { dents }(\mathbf{n}=\mathbf{4 4})\end{array}$ & $\begin{array}{c}\text { Coloured respon- } \\
\text { dents }(\mathbf{n}=\mathbf{3 6})\end{array}$ & $\begin{array}{c}\text { Total \% respon- } \\
\text { dents }(\mathbf{n}=\mathbf{1 4 2})\end{array}$ \\
\hline No response & 13 & 12 & 10 & 25 \\
\hline Old & 39 & 2 & 2 & 30 \\
\hline Young & 9 & 27 & 24 & 42 \\
\hline Don't know & 1 & 3 & & 3 \\
\hline
\end{tabular}

* The numbers in the first three columns are the actual number of responses out of the total indicated at the top of the column, while the last column represents the $\%$ of the total number of respondents 
well-supported in literature, which encourages producers who aim at producing whole carcasses for marketing in butcheries or in supermarkets, to consider using breeds with short backs in order to improve the appearance of the carcass (Dalle Zotte, 2002). These rabbits include the New Zealand White, California and German breeds.

Only $18 \%$ of the respondents who consume rabbit meat $(n=142)$ indicated that they would choose a rabbit carcass with a long body, because they believe that it has more meat. This might be partly true, because Arrington and Kelly (1976:176-201) said farmers producing rabbit meat for pre-packed portions are advised to go for breeds with longer backs and a slender short front section, as they produce higher yields of the valuable pieces - these include Giants and the Belgian hare. However, according to Green (1999), there is little difference between the two breeds, so the choice depends entirely on personal preference.

\section{Packaging of rabbit meat}

The respondents who consume rabbit meat were asked to specify if they would pay special attention to the packaging of rabbit meat. The results (Table 7) indicated that $41 \%$ would not pay special attention to the packaging while purchasing rabbit meat, while $36 \%$ would. Although the difference between all 'yes' and 'no' responses was not great, a highly significant difference was observed between ethnic groups $(p<0,01)$ regarding this issue. More white respondents $(50 \%)$ would pay special attention to the packaging of rabbit meat compared to black (31\%), and coloured respondents $(28 \%)$.

Respondents were asked to state the reasons why they think packaging is important in the marketing of rabbit meat. In response to this question they pointed out that packaging should allow them to see what the meat looks like (12\%). They further suggested that meat in packages will look more attractive if it is in portions of four and arranged similarly to chicken (12\%). Packaging should reflect cleanliness and hygiene $(8 \%)$, and display the colour of the meat $(1 \%)$. Six per cent of the respondents prefer the meat to be vacuum-packed, with the sell by-date, weight of meat and date of packaging indicated on the packaging material, a requirement of the present draft legislation pertaining to the labelling and marketing of food stuffs (Department of Health, 2002).

\section{Visual and physical attributes}

Respondents were asked to rate the visual and physical attributes according to the extent to which they would consider them when purchasing rabbit meat. This is because, like all other livestock, rabbit meat products are also evaluated in terms of meat quality and carcass quality (Dalle Zotte, 2002). In this regard, characteristics of a product that are in accordance with consumers' expectations will determine the sale of the product (Warriss, 2000:37-39). This will enable producers to produce a product that satisfies consumers' specification regarding economic objectives, such as meat yield and attractiveness to the consumer (Dalle Zotte, 2002; Warriss, 2000:37-39).

Colour According to Warriss (2000:37-39), colour is a major determinant of appearance. Appearance is important because it is practically the only criterion the consumer can use to judge the acceptability of most meat at the point of purchase. Forrest et al (1975:113114) asserts that the colour of meat is the overall first impression seen by the eye.

The results indicated a significant difference between ethnic groups $(p<0,05)$ when considering colour as an important meat quality attribute. Table 8 illustrates that the respondents who consume rabbit meat are concerned about colour when they purchase rabbit meat $(21 \%, n=30)$. This number resulted from 15 white respondents, 8 coloured respondents and 7 black respondents. These results are substantiated by Warriss (2000:37-39), who states that the colour of cooked or raw meat is an important characteristic in the choice of meat, because consumers associate it with the product's freshness, and they decide whether or not to buy the product based on their opinion of its attractiveness.

Shape/Arrangement The three-dimensional appearance was one of the most important attributes, according to the rating of the respondents. This attribute is influenced by the number of portions, type of portions, the size and placement of the portions in the package (Ouhayoun, 1998:177-195). The number of respondents who consume rabbit meat and who indicated that they, to a large extent $(29 \%$; $n=41)$, take note of shape and form was significantly higher than the values obtained from respondents who consume rabbit meat and who minded shape and form to a moderate extent $(8 \%)$, and from those who do not take it into account at all (4\%) (Table 8).

Ethnic groups differed significantly $(p<0,02)$ in the consideration of shape/arrangement when purchasing rabbit meat. Eighteen white respondents, 13 coloured respondents and 10 black respondents considered this trait to a large extent.

Weight Respondents who consume rabbit meat also regarded weight to a large extent $(29 \%$; $n=41)$ when purchasing rabbit meat. This number is significantly higher than those who consider weight to a moderate extent (4\%) and those who do not take note of weight at all (4\%).

Odour This is one of the organoleptic properties which could also influence consumers' decision to purchase rabbit meat. Respondents were requested to rate the extent at which they would consider the odour of rabbit meat during purchase. Table 8 illustrates that a large number of respondents who consume rabbit meat $(22 \% ; n=31)$ would consider odour as an important attribute when purchasing rabbit meat. This value mainly reflected the opinion of white respondents $(n=12)$, which was similar to that of the coloured respondents $(n=11)$, but higher than that of the black respondents $(n=8)$. 


\section{Age of rabbit for meat (old/young)}

Rabbit meat is available as fryers, roasters, stewers, and in rare cases, even capons. For the novice grower, an understanding of consumers' choice and reasons for their choice regarding this classification is essential for a successful rabbit meat business. To obtain information in relation to this type of choice, respondents were asked to indicate whether they would prefer to eat an old or a young rabbit. The results (Table 9) confirmed the findings reported by Arrington and Kelly (1976:176-201) and Lamar (1998) that the greatest demand is for fryer rabbits that are young, tender and meaty. These are rabbits that are not over 12 weeks of age, and for some processors they even prefer these fryers not to be over 10 or 11 weeks of age. In this study $42 \%$ of respondents who consume rabbit meat would prefer a young rabbit. This number was composed of 27 white respondents, 24 coloured respondents and 9 black respondents $(p<0,01)$. Respondents further gave a variety of reasons for their choice: $38 \%$ said the meat is more tender while an animal is still young; another 9\% stated that the meat of a young animal is tastier and juicier; while some felt young rabbits are healthier than old ones (2\%). It was also interesting to find that some respondents noted that they would choose a young rabbit because it looks more innocent than the old one (2\%).

On the other hand, the results also disclosed that there is another group of people who prefer the meat of an old animal as opposed to a young one (30\%). They supported their choice with a number of reasons:

Nineteen per cent indicated that an old rabbit is chewy, tasty and not sticky. Their opinions are in agreement with Warriss (2000:37-39) that the size of muscle fibres increases with increasing age and may be tougher. At 12 weeks of age, the hormones in rabbits start activating. Testicles appear on the bucks, while the doe's reproductive system begins to blossom. The hormones involved in this process have a direct bearing on the tenderness of the meat - the meat becomes tough (Lamar, 1998). Although many people prefer their meat to be tender, it is important to note that many Africans prefer their meat chewy - a fact substantiated by this study. Twenty seven per cent of the respondents who preferred the meat of an old animal were black (Table 9).

Another argument in favour of the older animal from some of the respondents (6\%) was that the older the animal becomes, the more the meat qualities develop. These results are supported by the findings from Gondret et al (1998), namely that flavour tends to develop with age; likewise juiciness depends largely on the fat content of the carcass. As age increases there is a marked accumulation of fat in the $m$ longissimus lumborum .

Although few of the respondents (2\%) associated age with size, respondents contradicted themselves and indicated that they would choose an old rabbit because of the fact that it has more meat. This view is supported by Warriss (2000:37-39), who notes that as animals grow they consequently increase in body weight and height. In addition the proportion of fat in their carcasses increases and the proportion of muscle and bone decreases.

One other interesting view from the respondents was that a young rabbit is still breeding, so it would be better to eat an old one. Considering these results it is important to note that prices paid for fryer (young) rabbits are higher than for roasters and stewers (Arrington \& Kelly, 1976:176-201; Lamar, 1998). According to Baldo as quoted by Billet (1992), it is advisable to cull a doe after six to eight matings. At this stage it will be sold for meat and this practice helps to maintain young stock which produces tender meat at a very good price.

\section{Lean or fatty meat}

Considering the fact that the amount of dissectible fat in rabbit carcasses is generally very low (about $3 \%$ ), it was important to ask the study population $(n=304)$ whether they prefer lean or fatty meat. Forty-six per cent of the respondents did not answer this question. As illustrated in Table 10, 37\% of the respondents seemed to like lean meat and argued that lean meat is healthy, has a low cholesterol content and that they dislike fat. A significance difference $(p<0,01)$ between the ethnic groups was observed. More white respondents preferred lean meat $(n=63)$, followed by coloured $(n=29)$ and black respondents $(n=19)$. These results prove that taking advantage of these traits of rabbit meat and putting them in the context of the Mediterranean diet, will be of great significance for this particular target market. On the other hand, 17\% of the respondents would like to have fatty meat and these were predominantly black respondents $(n=41)$. The reasoning behind their choice was that fat improves flavour - they dislike lean meat, and to them meat means fat. One other reason was that meat is very expensive; it is therefore much better to eat meat with a lot of fat in order to get a certain level of satisfaction in order to avoid having to buy more meat in a short while. This comment may have referred to the well-established fact that fat has a high satiety value (Grosvenor, 2000:202).

To satisfy the market for black consumers it is therefore important to bear in mind that rabbit meat, like all other meats, shows an increase in intramuscular fat (IMF) content with increase in age, provided the age differences are not too small (Gondret et al, 1998). With this in mind it can be concluded that an increase in IMF content could improve the eating quality of rabbit meat that is low in fat and generally considered to be insufficiently tasty and juicy. This can be achieved by delaying the age of slaughter, a trait also appreciated by the black respondents who consume rabbit meat.

Studies by Ouhayoun (1998:177-195) and Pla et al (1996) prove that large-sized rabbit breeds have a lower fat content than small ones, although the absolute value of these differences is small. 


\section{TABLE 10: $\quad$ PREFERENCE FOR LEAN OR FATTY MEAT PER ETHNIC GROUPS ( $n=304)^{*}$}

\begin{tabular}{|l|c|c|c|c|}
\hline $\begin{array}{c}\text { Choice of meat } \\
\text { per ethnic group }\end{array}$ & $\begin{array}{c}\text { Black respon- } \\
\text { dents (n=101) }\end{array}$ & $\begin{array}{c}\text { White respondents } \\
(\mathbf{n}=\mathbf{1 0 2})\end{array}$ & $\begin{array}{c}\text { Coloured respon- } \\
\text { dents }(\mathbf{n}=\mathbf{1 0 1})\end{array}$ & $\begin{array}{c}\text { Total \% respon- } \\
\text { dents }(\mathbf{n}=\mathbf{3 0 4})\end{array}$ \\
\hline No response & 41 & 35 & 65 & 46 \\
\hline Lean meat & 19 & 63 & 29 & 37 \\
\hline Fatty meat & 41 & 4 & 7 & 17 \\
\hline
\end{tabular}

* The numbers in the first three columns are the actual number of responses out of the total indicated at the top of the column, while the last column represents the $\%$ of the total number of respondents

TABLE 11: PLACES WHERE RESPONDENTS WOULD LIKE TO BUY RABBIT MEAT ( $n=142)$ *

\begin{tabular}{|l|c|c|c|c|}
\hline $\begin{array}{c}\text { Procurement of } \\
\text { rabbit meat }\end{array}$ & $\begin{array}{c}\text { Black respon- } \\
\text { dents (n=62) }\end{array}$ & $\begin{array}{c}\text { White respon- } \\
\text { dents }(\mathbf{n = 4 4 )}\end{array}$ & $\begin{array}{c}\text { Coloured respon- } \\
\text { dents (n=36) }\end{array}$ & $\begin{array}{c}\text { Total \% respondents } \\
(\mathbf{n = 1 4 2})\end{array}$ \\
\hline Domestic breeders & 17 & 4 & 0 & 15 \\
\hline Supermarkets & 15 & 28 & 15 & 41 \\
\hline Restaurants & 6 & 20 & 7 & 23 \\
\hline Hunters & 31 & 4 & 7 & 30 \\
\hline Butcheries & 26 & 27 & 9 & 44 \\
\hline
\end{tabular}

* The numbers in the first three columns are the actual number of responses out of the total indicated at the top of the column, while the last column represents the $\%$ of the total number of respondents

\section{Procurement of rabbit meat}

To investigate the most suitable places to sell rabbit meat, respondents were asked to indicate with a 'yes' or 'no' to specified places. Significant differences between ethnic groups were demonstrated in the choices of respondents about where to buy rabbit meat $(p<0,01)$. Generally speaking, the results show that respondents would either buy from butcheries (44\%) or supermarkets (41\%) (Table 11).

Although $41 \%$ of consumers disclosed that they would prefer to buy rabbit meat from the supermarket, this value was a result of a larger number of white respondents $(n=28)$ and smaller numbers of black $(n=15)$ and coloured respondents $(n=15)$. Table 11 further shows that $23 \%$ of respondents were willing to buy rabbit meat from restaurants; this percentage consisted predominantly of white $(n=20)$ respondents.

When it comes to procuring rabbit meat from hunters, $30 \%$ of the rabbit consumer respondents $(n=142)$ indicated that they would buy rabbit meat directly from them. Ethnic groups differed $(p<0,01)$ in this regard. Only four white and seven coloured respondents would buy rabbit meat from hunters, while 31 black respondents would do so. Only 4 white respondents would buy meat directly from the rabbit breeders compared to 17 black respondents.

The respondents indicated that they would mainly not purchase from domestic breeders $(23 \%)$ or from hunters (21\%). This was particularly so for white respondents (Table 12), who preferred to purchase at supermarkets and butcheries (Table 11).

\section{Price}

Dalle Zotte (2002) argues that the higher production cost of rabbit meat in developed countries compared to other meats is too prohibitive. The production costs for rabbits are twice as high as for chicken broilers and about 20 to $30 \%$ higher than for pigs. This implies that rabbit meat consequently becomes more expensive than other white meats and thus its consumption is automatically decreased. Respondents were asked to indicate whether price could influence their decision to purchase rabbit meat. The results revealed that a larger number of respondents who consume rabbit meat (49\%) would definitely consider price, whilst only $8 \%$ indicated that price would not influence their purchase (Table 13).

Respondents were requested to express their opinions on whether they would be prepared to pay more, less or the same price for the rabbit meat compared to chicken. Table 14 illustrates that $61 \%$ of respondents who consume rabbit meat would like to pay less than for chicken, which represented 18 white, 18 black and 14 coloured respondents.

There was a considerably lower percentage (37\%) that would be prepared to pay more for rabbit meat than chicken and $2 \%$ would pay a similar price to chicken. These results were in agreement with Hoffmann et al (1992), that a higher price for rabbit meat compared to other meat is a limiting factor in the marketing of rabbit meat.

It appeared as if respondents expected that it should be possible to market rabbit at a cheaper price than for chicken. The reality, however, is that, when considering the cost of feeding the animals, and the rate of 
production, it would not be possible to market rabbit meat as a cheaper product.

\section{Marketing of offal}

McCracken (1994) suggested that, due to the continuous increase in price of red and white meat, offal is the most affordable alternative protein source. However, $83 \%$ of the respondents in this study indicated that they would not be willing to eat rabbit offal. Of the few respondents who indicated that they would consume rabbit offal, most preferred livers (21\%) followed by the heart $(13 \%)$. The least preferred items were lungs $(12 \%)$, followed by the gastrointestinal tract (9\%).

\section{CONCLUSIONS AND RECOMMENDATIONS}

The ethnic groups in this study seemed to differ significantly regarding various factors affecting the marketing of rabbit meat. These include consideration of the form and presentation of rabbit meat for sale. Although the general demand is for portions, white respondents represented the highest proportion for this requirement. It is for this reason that white respondents disclosed that they would not mind purchasing rabbits without a head, while black respondents insisted that a rabbit should have a head attached, to ensure that it is a rabbit and not a cat. Significant differences were also observed on the choice of places to purchase rabbit meat. Supermarkets, butcheries and restaurants were ranked high by white and coloured respondents, while black respondents rated hunters and butcheries more highly. A large percentage of consumers of rabbit meat $(60 \%)$ indicated that they were not willing to pay more for rabbit meat than for chicken. This particular finding is further proof that there is a large shortcoming in the marketing of the positive aspects of rabbit meat that needs to be addressed.

\section{REFERENCES}

ALLEN, AH. 1995. Success in the supermarket by translating trends. Food Product Design. [Online] h t t p : / / w w w . food p roductdesign.com / archive/1995/0296PR.html\#top. Accessed 20 October 2002.

ASP, EH. 1999. Factors affecting food decisions made by individual consumers. Food policy 24 $(2,3): 287-294$.

ARRINGTON, LR \& KELLY, KC. 1976. Domestic rabbit biology and production. Gainesville. The University Press of Florida.

BILLET, R. 1992. New hope for rabbit farming: Small holder. Farmer's Weekly 30 October 1992:54-56.

DALLE ZOTTE, AD. 2002. Perception of rabbit meat quality and major factors influencing the rabbit carcass and meat quality. Livestock Production Science 75(1):11-32.

DEPARTMENT OF HEALTH. 2002. Draft regulations for the labelling and marketing of foodstuffs. R1055. Government Gazette 446(23714). Pretoria.

EADY, SJ \& PRAYAGA, K.2000. Rabbit farming for meat production in Australia: Profitability in the industry and economic values for production traits. Proceedings of the $7^{\text {th }}$ World Rabbit Congress. Valencia. FORREST, JC, ABERKE, ED, HEDRICL, HH, JUDGE, MD \& MERKEL RM. 1975. Principles of Meat Science. San Francisco. Freeman.

FRANKFORT-NACHMIAS, CF \& NACHMIAS, D. 1996. Research methods in the social sciences. 5th ed. London. Arnold.

GITTENS, C. 2000. Encouraging the rabbit habitat. Farmer's Weekly 26 May 2000:50-53.

GONDRET, F, JUIN, H, MOURT, J \& BONNEAU, M. 1998. Effect of age at slaughter on chemical traits and sensory quality of longissimus lumborum muscle in the rabbit. Meat Science 48(2):181-187.

GREEN, M. 1999. Breeding guidelines. Farmer's Weekly 16 July 1999:16-18

GROSVENOR, S. 2000. Nutrition: Science and applications. 3rd ed. Orlando. Harcourt.

HOFFMANN, IM, KOBLING S, STIER C-H \& GALL, C F. 1992. The potential of rabbit meat marketing in Bobo-Dioulasso, Burkina Faso. Livestock Research for Rural Development 4(1):1-7.

LAMAR, P. 1998.Colour Versus White. [Online] http:// www.3-cities.com/ fuzyfarm/Meat-rab.htm. Accessed 10 November 2002.

McCRACKEN, P. 1994. Consumer eye. Pot luck, for some. Farmer's Weekly 5 August 1994:28

MERMELSTEIN, NH. 2002. A look into the future of food science \& technology. Food Technology 56 (1):46-55

NKHABUTLANE, P. 2004. The perceptions of different ethnic groups on rabbit meat consumption. Thesis for Master's Degree in Natural Science in Consumer Science, University of Stellenbosch.

OUHAYOUN, R. 1998. Influence of the diet on rabbit meat quality. In The Nutrition of the Rabbit. London. CAB International. PILES, M, BLASCO, A \& PLA, M. 1999. The effect of selection for growth rate on carcass composition and meat characteristics of rabbits. Meat Science 54(4):347-355.

PLA, M., HERNANDEZ, P \& BLASCO, A. 1996. Carcass composition and meat characteristics of two rabbit breeds of different degrees of maturity. Meat Science 44(1):85-92.

SANDFORD, JC. 1986. The domestic rabbit. London. Collins.

SAS (1999). SAS/STAT Userguide, version 8. Vol. 2. SAS International. North Carolina.SAS Compass Drive. Cary.

SCHUTTE, De W. 1992. Notes on the dendrogram technique for the development of questionnaires. Cape Town. Human Sciences Research Council.

SLOAN, AE. 1999. Top ten trends to watch and work on for the millennium. Food Technology 53(8):4060.

SLOAN, AE. 2002. The Top 10 Functional Food Trends: The Next Generation. Food Technology 56 (4):32-57.

SONANDI, A, MASIKA, PJ \& VAN AVERBERKE, W. 1996. Rabbit production systems in selected areas of five provinces in South Africa. Proceedings of the $6^{\text {th }}$ World Rabbit Congress, Toulouse 3:429-434.

STILLINGS, BR. 1994. Trends in Foods. Nutrition Today 29(5):6-13.

WARRISS, PD. 2000. Meat Science: An Introductory Text. Wallingford. CABI. pp.37-39. 